\title{
Colombian stingless bee honeys characterized by multivariate analysis of physicochemical properties
}

\author{
Yaneth CARDONA, Alexandra TORRES, Wolfgang HOFFMANN \\ Departamento de Química, Grupo de Biocalorimetría, Universidad de Pamplona, km 1 Vía Bucaramanga, Pamplona, \\ Colombia
}

Received 4 February 2019 - Revised 23 August 2019 - Accepted 9 October 2019

\begin{abstract}
In this study, which took place from August 2014 to August 2015, we looked at the physicochemical properties of honey produced by seven species of stingless bees and the honey bee (Apis mellifera). Every 2 months, we took honey samples from the Apis mellifera, Melipona fuscipes, Melipona favosa favosa, and Melipona compressipes, and every 3 months, samples were taken of Trigona (Frieseomelitta) nigra, Scaptotrigona sp., Nannotrigona sp., and Trigona (Tetragonisca) angustula. The results showed that the physicochemical properties depend on bee species $(p<0.05)$ and not on the time of year $(p>0.05)$. In addition, the samples were 97.2\% correctly classified using multivariate analysis. We found that the water content, refractive index, total sugars, total acidity, diastase, $\mathrm{pH}$, and hydroxymethylfurfural (HMF) have a discriminant power of $p<0.05$
\end{abstract}

\section{honey / stingless bees / physicochemical properties / Melipona species / multivariate analysis}

\section{INTRODUCTION}

Honey is a complex mixture made by bees from the nectar of flowers or honeydew. The most common and commercialized honey worldwide is produced by Apis mellifera; however, in tropical countries, there are stingless bees. These bees are considered "stingless" because the size of the sting is greatly reduced and its vestigial nature makes it difficult to utilize this mechanism (Torres et al. 2007; Dardón et al. 2013). Stingless bees produce a specific type of honey called "pot honey" because it is stored in pot-shaped wax containers. Several studies have shown that pot honey and honey bee honey have dissimilar values regarding their physicochemical properties, especially moisture content, which is less

Corresponding author: A. TORRES,

datorres@unipamplona.edu.co

Manuscript editor: James Nieh than $20 \%$ in A. mellifera honey and $20-40 \%$ in pot honey. Therefore, further investigations on pot honey properties are required to improve its consumption and to protect the bees and their natural habitat (Bijlsma et al. 2006; Chuttong et al. 2016).

Most investigations related to physical properties and the chemical composition of honeys are related to the different types of honeys (monofloral and multifloral from nectar and honeydew honey) produced by Apis mellifera, and there are few studies of honeys produced by stingless bees (Vit et al. 1998). Due to the limited number of studies focused on stingless bee honey (Vit et al. 1998), Vit et al. (1998) recommended to collect information from different sources and build up a common database with harmonized methods of analysis of quality factors of pot honey in order to develop adequate standards for these honeys. Most studies related to physicochemical properties of these honeys can be found in Pot Honey: A Legacy of Stingless Bees, which summarizes its relationships with the diversity of 
species, geographic factors, importance in agricultural and natural ecosystems, chemical characteristics, and its applications in different fields (Roubik et al. 2013).

Multivariate analysis techniques have been used to determine the geographical origin of honey based on free amino acid content (Gilbert et al. 1981). These techniques were used to classify and differentiate nectar and honeydew honeys according to physicochemical and palynological parameters (Bentabol Manzanares et al. 2011; Cardona et al. 2017), to predict the entomological origin of stingless bee honeys based on compositional factors (Vit et al. 1998), and to classify honey from different botanical origins (Persano Oddo et al. 1988).

The quality of honey depends on its composition and physicochemical properties. However, these values vary depending on the floral source visited by the bee. Bearing in mind that the vegetation from which the bees collect nectar, and depending on the weather and season, it is possible that there exists differences in physicochemical properties of honeys collected in different seasons due to the variation of floral resources. In this study, we present for the first time the values of physicochemical properties as observed during 1 year (in both dry and rainy periods) in honeys produced by several species of stingless bees, which include Trigona nigra, T. angustula, Scaptotrigona sp., Nannotrigona sp., Melipona compressipes, Melipona favosa favosa, and Melipona fuscipes. We compared these with Apis mellifera honey from Norte de Santander, Colombia. To classify these honeys, we used principal component analysis (PCA).

Some physicochemical properties of honeys produced by stingless bees from countries such as Colombia, Venezuela, Brazil, Guatemala, and Mexico have been reported to contain ash contents of $0.2-7.7 \%$ (T. angustula) (Santiesteban-Hernández et al. 2003; Fuenmayor et al. 2012), 0.06$0.31 \%$ (Scaptotrigona sp.) (Vit et al. 1998; Fuenmayor et al. 2013$), 0.33 \%$ (Nannotrigona sp.) (Fuenmayor et al. 2013), 0.01-29\% (M. favosa) (Vit et al. 1994; Fuenmayor et al. 2013), 0.09-0.30\%
(M. compressipes) (Vit et al. 1994; Fuenmayor et al. 2013), and 0.04-1.72\% (A. mellifera) (Alqarni et al. 2014; Boussaid et al. 2014; Karabagias et al. 2014a, b, d; Özcan and Ölmez 2014). There are no publications about ash content of honey produced by $T$. nigra and $M$. fuscipes.

Additionally, the ash content of different types of honey produced by A. mellifera was determined to be primarily botanical in origin, meaning that the ash content depended on location and the floral resources available to the bee (Esti et al. 1997; Felsner et al. 2004). This property has been used in conjunction with microscopic and organoleptic characteristics of honey, which differentiate honeydew honey from blossom honey (Terrab et al. 2004; Habib et al. 2014; Karabagias et al. 2014a, b, d; Bettar et al. 2015).

The electrical conductivity values reported in the literature are $M$. favosa $(0.44-2.06 \mathrm{mS} / \mathrm{cm})$ (Bogdanov et al. 1996; Vit et al. 1998), M. compressipes $(0.32-8.77 \mathrm{mS} / \mathrm{cm}$ ) (Vit et al. 1994; Souza and Bazlen 1998), T. nigra (1.04 \pm $0.26 \mathrm{mS} / \mathrm{cm}$ ) (Bogdanov et al. 1996), T. angustula (0.66-7.3 mS/cm) (Vit et al. 1998; Fuenmayor et al. 2012), and Scaptotrigona sp. (0.39-2.9 mS/cm) (Vit et al. 1998; Fuenmayor et al. 2013). The reported $\mathrm{pH}$ values of honey for Apis mellifera are 3.20 to 6.10 (White 1975, 1978).

\section{MATERIALS AND METHODS}

\subsection{Honey samples}

Honey samples were collected from sealed honey pots of stingless bee hives located in three towns in Norte de Santander, Colombia, from August 2014 to August 2015: every 3 months for: T. nigra, T. angustula (Los Patios), Scaptotrigona sp., Nannotrigona sp. (Pamplonita); and every 2 months for: M. fuscipes (Pamplonita), A. mellifera (Carmen de Tonchalá), M. favosa, and M. compressipes (Los Patios).

Honey samples were protected from the light at a room temperature of $\sim 20^{\circ} \mathrm{C}$. The sampling time and the places where bees are located were selected due the quantity of honey that they produce and its availability, respectively. 


\subsection{Physicochemical parameters}

The physicochemical parameters measured in the honeys were ash content, $\mathrm{pH}$, moisture percentage, acidity (free, lactonic, and total), electrical conductivity, diastase activity, hydroxymethylfurfural (HMF), and total sugar content. The methodology proposed by The Official Methods of Analysis of the Association of Official Analytical Chemists (Association of Official Analytical Chemists 1990 ; AOACInternational 2000) and the International Honey Commission (2009) was used to determine all parameters in triplicate (Commission 2009).

\subsubsection{Ash content}

Two grams of honey was evaporated at $200{ }^{\circ} \mathrm{C}$ with a hot-plate magnetic stirrer (Boeco, $\mathrm{MSH}$ 300 , Hamburg, Germany) then heated to $550{ }^{\circ} \mathrm{C}$ for $6 \mathrm{~h}$ in a muffle furnace (Vulcan 3-550, Germany).

\subsubsection{Electrical conductivity}

Electrical conductivity was measured at $20{ }^{\circ} \mathrm{C}$ in an aqueous solution of honey $(20 \% \mathrm{w} / \mathrm{v})$ using a conductimeter (Inolab Multi Level 1).

\subsection{3. $\mathrm{pH}$}

$\mathrm{pH}$ was measured at $20{ }^{\circ} \mathrm{C}$ in an aqueous solution of honey $(1: 7.5)(13.3 \% \mathrm{w} / \mathrm{v})$ with a pH-meter (Inolab Multi Level 1).

\subsubsection{Acidity (free, lactonic, and total)}

Acidity was determined by titration of an aqueous honey solution $(13.3 \%$ w/v) with $\mathrm{NaOH}$ $0.05 \mathrm{M}$ until a $\mathrm{pH}$ of 8.50 was reached (free acidity). After that, $10 \mathrm{~mL}$ of $\mathrm{NaOH}(0.05 \mathrm{M})$ was added to start back titration with $\mathrm{HCl}$ $0.05 \mathrm{M}$ until a $\mathrm{pH}$ of 8.30 was reached (lactonic acidity).

\subsubsection{Moisture content}

The moisture content was measured at $20{ }^{\circ} \mathrm{C}$ using an Abbe refractometer (Brixco, model
3030). The refractive index values were then converted to water percentage using the Wedmore equation (E. 1995).

\subsubsection{Diastase activity}

The diastase activity was determined by measuring the velocity of hydrolysis of starch in a buffer solution of honey at $40{ }^{\circ} \mathrm{C}$. The final point of this reaction was determined measuring the absorbance at $660 \mathrm{~nm}$ in a spectrophotometer UV-Vis (Shimadzu, UV-2401PC, Japan).

\subsubsection{Hydroxymethylfurfural}

HMF content was determined after clarifying honey samples with Carrez reagents (I and II) and mixed with sodium bisulfite. Absorbance was measured at 284 and $336 \mathrm{~nm}$ in a spectrophotometer (Shimadzu, UV-2401PC, Japan).

\subsubsection{Total sugar content}

The total sugar content was determined at 20 ${ }^{\circ} \mathrm{C}$ with an Abbe refractometer $\left(0-95^{\circ} \mathrm{Bx}\right.$, Brixco, model 3030).

\subsection{Statistical multivariate analysis and principal component analysis}

The Statistical Package for Social Sciences (SPSS) for Windows (Demo version 19; SPSS Inc., Chicago, IL, USA) was used for all statistical analysis. Analysis of variance (ANOVA) $(p<$ 0.05 ), followed by the Bonferroni test, was used to establish if there were significant differences in the physicochemical parameters of honeys collected during the course of 1 year from August 2014 to August 2015.

We used a factorial analysis to reduce the dimensionality of the data in order to find the minimal number of physicochemical parameters that can explain the maximum of data information. By the results obtained with KMO (Kaiser-MeyerOlkin) $(p>0.5)$ and Bartlett's test $(p<0.001)$, we classified the honey samples produced by different species based on their physicochemical properties using principal component analysis (PCA). 


\section{RESULTS}

The honey samples have physicochemical characteristics which were measured using several laboratory analyses and can be separated into different groups by their relation to the maturity, purity, and the deterioration of the samples. Table I shows the values of physicochemical properties.

\subsection{Statistical analysis}

In the statistical analysis done with the obtained results, we found that the first four components represent $88.7 \%$ of that total variation of all variables measured. The F1 component $(37.31 \%)$ is mainly explained by water content, refractive index, total sugars, and total acidity; the F2 component $(25.09 \%)$ is mainly explained by HMF, diastase and $\mathrm{pH}$, the $\mathrm{F} 3$ component (14.44\%) by ash content and electrical conductivity and the F4 component $(11.83 \%)$ by acidity (lactonic and free). Components F1 and F2 explained $62.40 \%$ of total variance, indicating that the honey samples produced by different species of bees can differentiate between them, using some of its physicochemical parameters.

The parameters that are required for classification of honey samples are in accordance with several parameters selected in other studies for classifying different types of honey, such as Pena Crecente and Herrero Latorre 1993 (moisture and acidity) (Pena Crecente and Herrero Latorre 1993); Terrab et al. 2002 (moisture, acidity (free and lactonic), $\mathrm{pH}$, and proline) (Terrab et al. 2002); Krauze and Zalewski 1991 (electric conductivity, free acidity, proline, and $\mathrm{pH}$ ) (Krauze and Zalewski 1991); Amina Chakir 2011 (acidity, color, HMF, and diastase) (Chakir et al. 2011); and Sanz et al. 1995 (acidity, pH, electrical conductivity, ash content, HMF, and diastase) (Sanz et al. 1995).

\section{DISCUSSION}

\subsection{Maturity of honey}

The maturity of the food is determined by evaluating sugar and moisture content. The water content of honey is related to its stability during storage (Sopade et al. 2003). This parameter depends on several aspects such as climatic factors, harvest season, and the maturity degree reached in the hive. This parameter also is a quality criterion, which determines the capacity of the food for avoiding the fermentation of yeasts, meaning the higher the water content, the higher the probability of honey samples will ferment during the storage process. For honey produced by Apis mellifera, the recommended value of moisture is less than $19 \%$ for a longer shelf life; pot honey, however, presents higher values (Ojeda de Rodríguez et al. 2004; Bijlsma et al. 2006; Finola et al. 2007).

The water percentage found in honeys of T. angustula (24.6 \pm 1.2$),$ M. favosa (25.0 \pm $0.7)$, M. compressipes (22.5 \pm .6$)$, and Nannotrigona sp. $(30.2 \pm 0.7)$ is in accordance with previous studies. The mean value of honey produced by $T$. nigra species $(28.2 \pm 1.0)$ is lower than reported in the literature, while for Scaptotrigona sp. honey $(31.0 \pm 0.5)$, the mean value is higher. The mean water content of M. fuscipes honey through the year was $26.7 \pm$ 1.0. A multifactor analysis of variance showed that the percentage of moisture depends on the bee species $(p<0.05)$ and not on period of year.

According to the literature, pot honey could rapidly ferment due its moisture content (Sopade et al. 2003). Nevertheless, we observed that honeys collected in August 2014 conserved their original flavor as described by other researchers (Bijlsma et al. 2006). This fact can indicate that the "high" moisture content of these honeys is due to one specific control mechanism made by bees to preserve honey for long periods of time. We used a MANOVA, and the results showed that the moisture content depends on bee species $(p<$ $0.05)$ and not the time of year $(p>0.05)$.

On the other hand, sugars are principal components of both honey bee honey and stingless bee honey. They depend on the floral resource used by the bees to make their honey. The majority of sugars are fructose and glucose (53.7-73.1\%) and these are generally in the same proportions (Vit et al. 1998); while the quantity of other sugars such as maltose and some oligosaccharides are at a trace level (Bogdanov et al. 1996; Vit 2013). The 


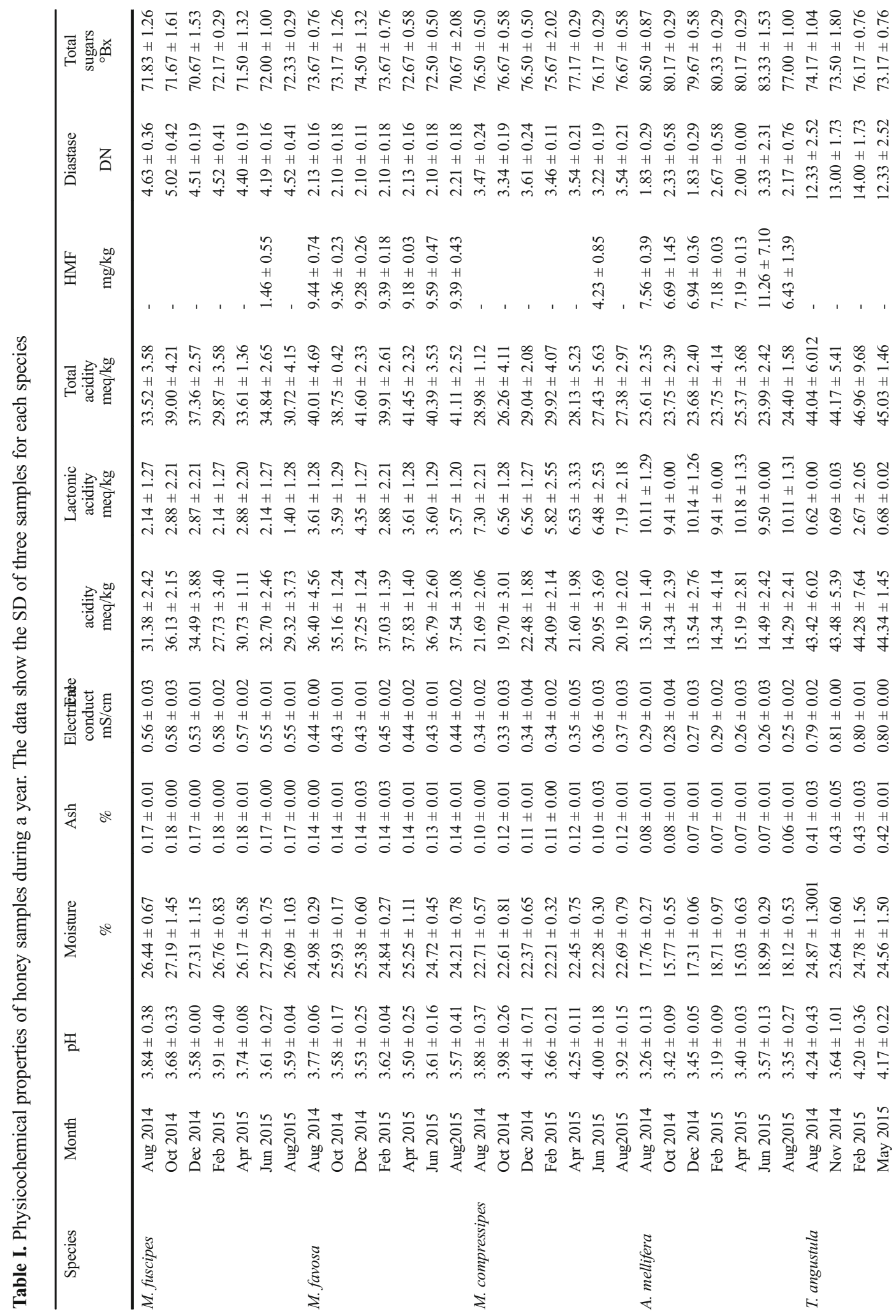




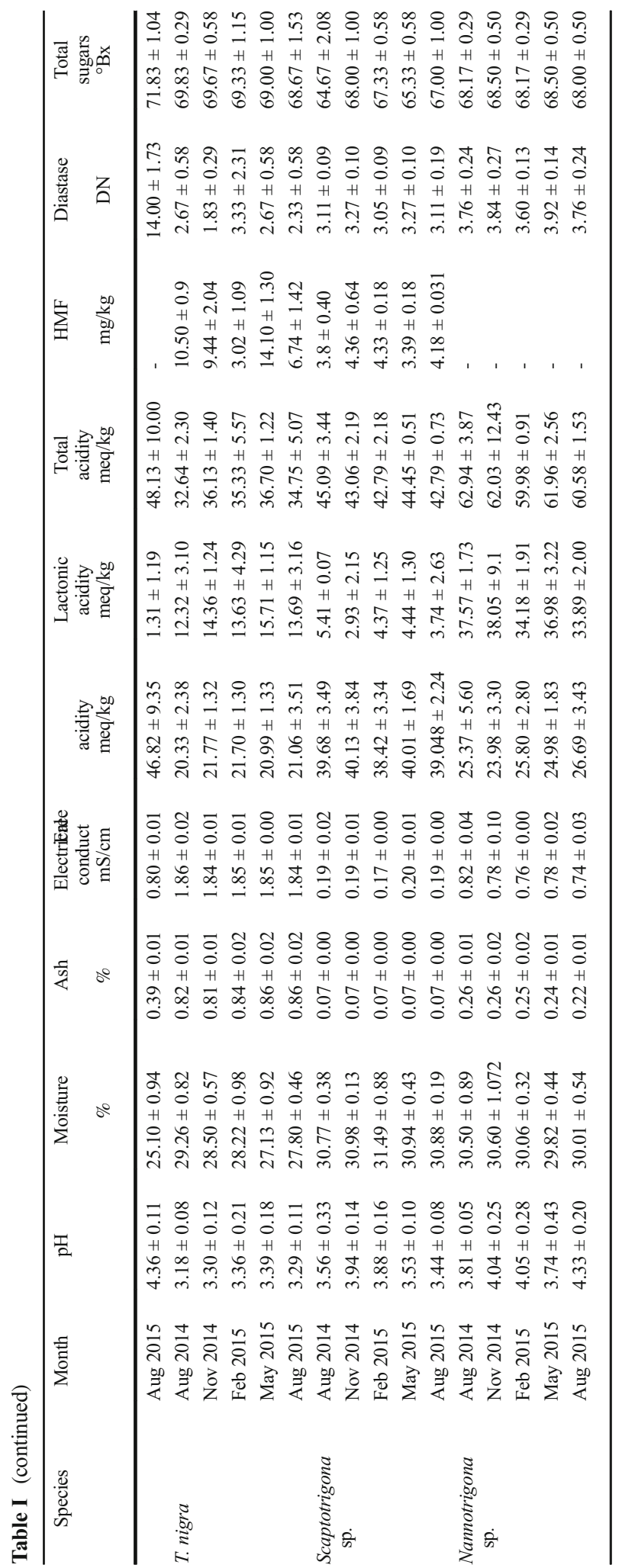


total sugar content in this study was measured using the refractometric method, and the range values obtained were as follows: $71-77{ }^{\circ} \mathrm{Bx}$ (T. angustula ); 67-70 ${ }^{\circ} \mathrm{Bx}$ (T. nigra); 63-69 ${ }^{\circ} \mathrm{Bx}$ (Scaptotrigona sp.); and 67.5-69.0 ${ }^{\circ} \mathrm{Bx}$ (Nannotrigona sp.), 69.0-73.5 (M. fuscipes), 69.0-75.5 (M. favosa), 73.5-77.5 (M. compressipes), and 76.0-85.0 (A. mellifera).

\subsection{Purity of honey}

The purity of honey is commonly evaluated using the solid insoluble content, ash content, and pollen present in the samples. Ash content is considered a criterion of quality for the origin of honey samples; in this instance, the floral honey has less ash content than honeydew honey. Ash content in honey samples varies $(0.02-1.0 \%)$, which may differ according to the practices and processes used to harvest honey; thus, it is possible to determine if the extraction process has been done with good manufacturing practices (Commission 2009; Oliveira and Santos 2011).

Several studies have reported values of this property for different bee species, and the obtained results can indicate that ash content also may depend on bee species that makes honey (Vit 2013). The most abundant mineral in honey is potassium and the least abundant minerals are iron, manganese, copper, chlorine, phosphorus, and sulfur. The ash content, the pollen, and the phenolic compounds affect the color of the honey. The values obtained in this work for ash content are in accordance with literature: Nannotrigona sp. $(0.25 \pm 0.02 \%)$, Scaptotrigona sp. $(0.07 \pm$ $0.01 \%)$, and $M$. favosa $(0.14 \pm 0.01 \%)$. The mean values found for honeys of $T$. angustula $(0.42 \pm$ $0.03 \%)$ and $M$. compressipes $(0.11 \pm 0.01 \%)$ are higher than those reported in other investigations.

On the other hand, the electrical conductivity of honey is related to the total concentration of minerals, salts, organic acids, proteins and some complex sugars (Atrooz et al. 2008; Belay et al. 2013; Yücel and Sultanog lu 2013; Boussaid et al. 2014), and the botanic origin of the specific honey (Terrab et al. 2004; Zhou et al. 2013). The electrical conductivity obtained from the honey samples in this study ranges from 0.19 to $1.85 \mathrm{mS} / \mathrm{cm}$ as follows: Trigona (Frieseomelitta) nigra (1.84-
$1.88 \mathrm{mS} / \mathrm{cm}$ ), Trigona (Tetragonisca) angustula (0.77-0.81 mS/cm), Nannotrigona sp. (0.71$0.89 \mathrm{mS} / \mathrm{cm})$, Scaptrigona sp. $(0.17-0.21 \mathrm{mS} /$ $\mathrm{cm})$, Melipona fuscipes $(0.52-0.60 \mathrm{mS} / \mathrm{cm})$, Melipona favosa favosa $(0.41-0.47 \mathrm{mS} / \mathrm{cm})$, Melipona compressipes $(0.30-0.41 \mathrm{mS} / \mathrm{cm})$, and Apis mellifera $(0.23-0.31 \mathrm{mS} / \mathrm{cm})$. A multivariate analysis of variance in the samples studied showed that the ash content and electrical conductivity depend on bee species $(p<0.5)$ and not time $(p>0.5)$.

\subsection{Deterioration of honey}

Several possible factors that may be used to measure the deterioration of honey are the $\mathrm{pH}$ values, acidity content, diastase content, and hydroxymethylfurfural (HMF). The acidity of honey is due to the presence of organic acids, mainly gluconic acid (Terrab et al. 2004) which is produced by the activity of glucose oxidase enzyme (Karabagias et al. 2014c). The acidity levels in honey can be associated with composition, harvest period, and floral resources; therefore, a variation in the total acidity values of different honeys could be an indicator of the presence of acids and alcohols produced by their fermentation. Honey content includes several enzymes of animal and plant origin; the most important are diastase (hydrolyze the starch to glucose) and invertase (hydrolyze the sucrose to glucose and fructose). Diastase is secreted by the hypopharyngeal glands of the bees, which are in the upper front of their head. Diastase activity can be used as an indicator of aging and excessive heating in the processing of honey, because this enzyme is unstable to heat and can deteriorate over time, which is why their levels decrease in these conditions (Gomes et al. 2010; Bentabol Manzanares et al. 2011; Can et al. 2015).

The $\mathrm{pH}$ values found in this work ranged between T. angustula (2.5-4.6), T. nigra (3.1-3.6), Scaptotrigona sp. (3.2-4.1) and Nannotrigona sp. (3.3-4.5), M. fuscipes (3.4-4.3), M. favosa (3.1-3.9), M. compressipes (3.4-5.0), and A. mellifera (3.1-3.7). The total acidity values were $25.9-43.7 \mathrm{meq} / \mathrm{kg}$ (M. fuscipes ), 34.8-43.9 $\mathrm{meq} / \mathrm{kg}$ (M. favosa), 21.8-33.9 meq/kg (M. compressipes), 19.0-28.6 meq $/ \mathrm{kg}$ 
(A. mellifera), 36.6-56.0 meq/ $\mathrm{kg}$ (T. angustula), 28.9-39.6 meq $/ \mathrm{kg}$ (T. nigra), 40.7-48.7 meq $/ \mathrm{kg}$ (Scaptotrigona sp.), and 51.8-75.9 meq/kg (Nannotrigona sp.).

In this study, we reported for the first time the values of acidity and $\mathrm{pH}$ for T. nigra and Nannotrigona sp. Our values agree with the values reported in other studies, and there is a higher acidity level in "pot honey" as compared with honey produced by A. mellifera . This high acidity in pot honey is produced by fermentation related to the higher moisture content. This process is a characteristic of these honeys and takes place spontaneously in the storage pots where the bees store nectar. The fermentation process is considered undesired in honey bee honey, but acceptable in pot honey because its acidity can improve is antioxidant capacity and can be used for medicinal purposes (Tuso 2014). A multivariate analysis of variance shows that $\mathrm{pH}$ and acidity (free, lactonic, and total) depend on the bee species $(p<0.5)$ and not the season $(p>0.5)$.

On the other hand, diastase activity and HMF content are parameters related to the freshness of honey due to the sensibility of these to an increase in temperature (Yücel and Sultanog lu 2013; Shantal Rodríguez Flores et al. 2015). HMF content is considered an important criterion for the evaluation of storage time of honey, and to know if this has been heated to avoid or decrease the crystallization process. In addition, this is related to changes in the natural color of honey and the appearance of a strange taste and smell, whereby it is one of the most evaluated quality parameters. The fresh honey can have low HMF levels, which rarely exceed $10 \mathrm{mg} / \mathrm{kg}$; however, higher levels can indicate the overheating or adulteration of the honeys (Gomes et al. 2010; Bettar et al. 2015).

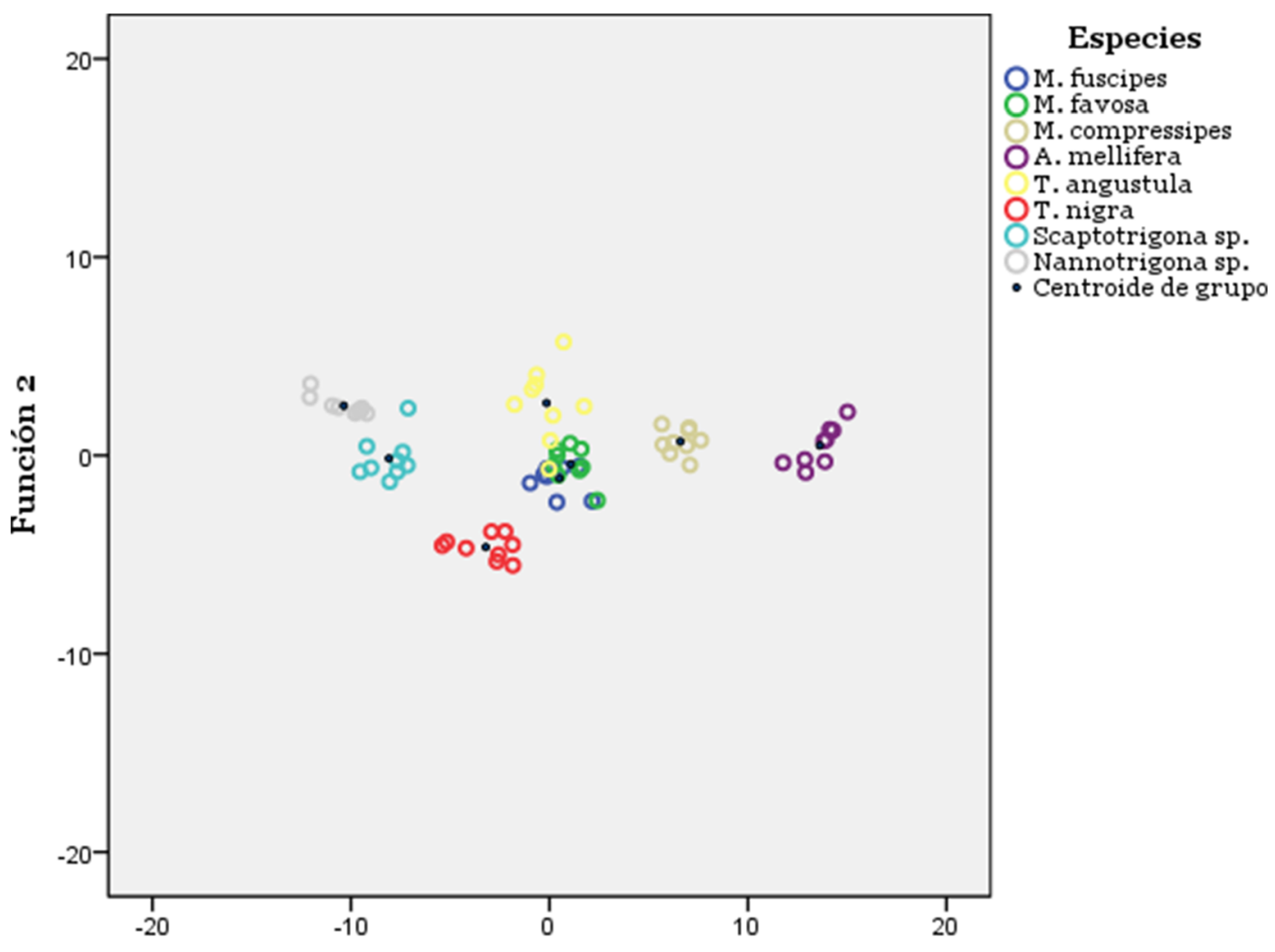

Función 1

Figure 1. Canonical discriminant functions. 
The diastase activity for the different samples, including the calculated SD, was found to range between 2.0-2.3 (M. favosa), 3.0-3.8 (M. compressipes ), 4.0-5.5 (M. fuscipes), 1.56.0 (A. mellifera), 3.0-3.3 (Scaptotrigona sp.), 3.5-4.0 (Nannotrigona sp.), and 1.5-6.0 (T. nigra), and was lower than the values found for honeys produced by T. angustula (10.0-15.0). These values are in aggreeance with other studies with the exception of $M$. fuscipes and T. nigra honeys, of which there are no reports.

In honey produced by $M$. fuscipes and M. compressipes, we found HMF only in the June samples, with values of $1.46 \pm 0.55 \mathrm{mg} / \mathrm{kg}$ and $4.23 \pm .85 \mathrm{mg} / \mathrm{kg}$, respectively. The honey of T. angustula and Nannotrigona sp. did not present HMF in any month throughout the year, while other honey samples presented values ranging between 8.65-10.12 (M. favosa), 5.10-19.42 (A. mellifera) and 2.11-14.84 (T. nigra), and 3.19-5.10 (Scaptotrigona sp.).

\subsection{Discriminant analysis}

Discriminant analysis indicated that water content, refractive index, total sugars, total acidity, diastase, $\mathrm{pH}$, and HMF have discriminant power $(p<0.05)$; this was confirmed by Wilks's lambda $(p<0.05)$, and the samples were $97.2 \%$ correctly classified. The canonical discriminant functions are shown in Figure 1.

In this study, we report for the first time the values of diastase and HMF for honey produced by M. fuscipes, $\mathrm{pH}$ and laconic acidity for honeys produced by T. nigra, M. compresipes, and Nannotrigona sp.; and free acidity in the honey samples produced by Scaptotrigona sp., T. nigra, M. fuscipes, and Nannotrigona sp. Additionally, we found that the physicochemical properties depend on bee species $(p<0.05)$ and not on the time of the year $(p>0.05)$. Therefore, these parameters can be used for differentiating honey samples. Physicochemical properties are different for Apis mellifera honey compared with stingless bee honey; for instance, the pot honey samples analyzed in this work have a higher water content, acidity (free and total), and ash content than honey produced by Apis mellifera ; furthermore, the honey produced by stingless bees has a lower sugar content and higher electric conductivity, with the exception of honey produced by Scaptotrigona sp. In spite of a "higher" water content found in pot honey samples, fermentation was not found in the samples. It can be related to the addition of enzymes or other compounds during the processing of nectar to honey inside the nest.

Finally, the water content, refractive index, total sugars, total acidity, diastase, $\mathrm{pH}$, and HMF have a discriminant power of $p<0.05$. The samples were $97.2 \%$ correctly classified, and this classification showed that honey samples produced by bees of the same genus do not necessarily have similar physicochemical properties, such as the Melipona species. Statistical analysis showed that acidity is the principal factor to differentiate between honey produced by Apis mellifera and stingless bees, which is in agreement with other authors.

\section{ACKNOWLEDGMENTS}

The authors would like to also thank Russell Burrell for his cooperation in revising and editing this article.

\section{AUTHORS' CONTRIBUTION}

Y.C. and W.F. sampled honey samples. Y.C. performed experiments and analyzed data. Y.C. and A.T. wrote the manuscript. All authors revised, read, and approved the final manuscript.

\section{FUNDING INFORMATION}

This work was supported by Ricola Foundation (Switzerland), within the framework of the project "Stingless bees as alternative pollinators" and the Universidad de Pamplona, Vicerrectoría de Investigaciones.

\section{COMPLIANCE WITH ETHICAL STANDARDS}

Conflict of interest The authors declare that they have no conflict of interest.

Disclaimer Not applicable. 
Propriétés physico-chimiques des miels d'abeilles sans dard de Colombie par une analyse multivariée.

\section{Miel / abeilles sans dard / propriétés physico-chimiques / espèces Melipona / analyses multivariées.}

\section{Physikochemische Eigenschaften von Honigen Stachelloser Bienen aus Kolumbien - Charakterisierung mittels multivariater Analyse}

\section{Honig / Stachellose Bienen / Physikochemische Eigenschaften / Melipona Arten / multivariate Analyse.}

\section{REFERENCES}

Alqarni A.S., A.A. Owayss, A.A. Mahmoud, M.A. Hannan. (2014) Mineral content and physical properties of local and imported honeys in Saudi Arabia. Journal of Saudi Chemical Society 18(5): 618-625.

AOACInternational K., Association of Analytical Communities. (2000) Official methods of analysis of AOAC International., in: AOACInternational K., Association of Analytical Communities. (Ed.), 17th ed, Gaithersburg,MD,USA.

Association of Official Analytical Chemists I.A. (1990) Official methods of analysis . Arlington, VA, USA: Association of Official Analytical Chemists, Inc., in: Chemists. A.A. (Ed.), 15th ed, Arlington,VA,USA.

Atrooz O.M., M.A. Al-Sabayleh, S.Y. Al-Abbadi. (2008) Studies on physical and chemical analysis of various honey samples and their antioxidant activities. J. Biol. Sci. 8 : $1338-1342$.

Belay A., W.K. Solomon, G. Bultossa, N. Adgaba, S. Melaku. (2013) Physicochemical properties of the Harenna forest honey, Bale, Ethiopia. Food Chem. 141 (4): 3386-3392.

Bentabol Manzanares A., Z.H. García, B.R. Galdón, E.R. Rodríguez, C.D. Romero. (2011) Differentiation of blossom and honeydew honeys using multivariate analysis on the physicochemical parameters and sugar composition. Food Chem. 126 (2): 664-672.

Bettar I., M.L. González-Miret, D. Hernanz, A. Marconi, F.J. Heredia, et al. (2015) Characterisation of Moroccan Spurge (Euphorbia) honeys by their physicochemical characteristics, mineral contents and colour. Arab. J. Chem. https://doi.org/10.1016/j.arabjc.2015.01.003.

Bijlsma L., L. L.M.d. Bruijn, E.P. Martens, M.J. Sommeijer. (2006) Water content of stingless bee honeys (Apidae, Meliponini): interspecific variation and comparison with honey of Apis mellifera. Apidologie 37 (4): 480-486.
Bogdanov S., P. Vit, V. Kilchenmann. (1996) Sugar profiles and conductivity of stingless bee honeys from Venezuela. Apidologie 27 (6): 445-450.

Boussaid A., M. Chouaibi, L. Rezig, R. Hellal, F. Donsì, et al. (2014) Physicochemical and bioactive properties of six honey samples from various floral origins from Tunisia. Arab. J. Chem.: https://doi.org/10.1016/j. arabjc.2014.08.011.

Can Z., O. Yildiz, H. Sahin, E. Akyuz Turumtay, S. Silici, et al. (2015) An investigation of Turkish honeys: Their physico-chemical properties, antioxidant capacities and phenolic profiles. Food Chem. 180 : 133-141.

Cardona Y., A. Torres, W. Hoffmann, I. Lamprecht. (2017) Differentiation of Honey from Melipona Species Using Differential Scanning Calorimetry. Food Analytical Methods: https://doi.org/10.1007/s12161-0171083-z.

Commission. I.H. (2009) Harmonised methods of the International Honey Commission, in: Commission I.H. (Ed.).

Chakir A., A. Romane, G.L. Marcazzan, P. Ferrazzi. (2011) Physicochemical properties of some honeys produced from different plants in Morocco. Arab. J. Chem.: https://doi.org/10.1016/j.arabjc.2011.10.013.

Chuttong B., Y. Chanbang, K. Sringarm, M. Burgett. (2016) Physicochemical profiles of stingless bee (Apidae: Meliponini) honey from South East Asia (Thailand). Food Chem. 192: 149-155.

Dardón M.J., C. Maldonado-Aguilera, E. Enríquez. (2013) The Pot-Honey of Guatemalan Bees, in: Vit P., Pedro S.R.M., and Roubik D. (Eds.), Pot Honey, Springer New York, pp. 395-408.

E. W. (1995) The accurate determination of the water content of honeys. Bee World 36 : 197-206.

Eduardo Solano-Becerra C.Y.P.-M., Otto German ParadaRivera. (2009) Identificación y caracterización de los eslabones, actores y agentes de la cadena productiva forestal madera muebles de la región norte de santander. Respuestas 14 (1): 66-76.

Egardt J., M. Mørk Larsen, P. Lassen, I. Dahllöf. (2018) Release of PAHs and heavy metals in coastal environments linked to leisure boats. Mar. Pollut. Bull. 127 : 664-671.

Esti M., G. Panfili, E. Marconi, M.C. Trivisonno. (1997) Valorization of the honeys from the Molise region through physico-chemical, organoleptic and nutritional assessment. Food Chem. 58(1-2): 125-128.

Felsner M.L., C.B. Cano, R.E. Bruns, H.M. Watanabe, L.B. Almeida-Muradian, et al. (2004) Characterization of monofloral honeys by ash contents through a hierarchical design. J. Food Compos. Anal. 17 (6): 737-747.

Finola M.S., M.C. Lasagno, J.M. Marioli. (2007) Microbiological and chemical characterization of honeys from central Argentina. Food Chem. 100 (4): 1649-1653.

Fuenmayor C., A. Díaz-Moreno, C. Zuluaga-Domínguez, M. Quicazán. (2013) Honey of Colombian Stingless Bees: Nutritional Characteristics and Physicochemical Quality Indicators, in: Vit P., Pedro S.R.M., and 
Roubik D. (Eds.), Pot-Honey, Springer New York, pp. 383-394.

Fuenmayor C.A., C.M. Zuluaga-Domínguez, A.C. DíazMoreno, M.C. Quicazán. (2012) 'Miel de angelita': Nutritional composition and physicochemical proper ties of Tetragonisca angustula honey. Interciencia 37 (2): 142-147.

Gilbert J., M.J. Shepherd, M.A. Wallwork, R.G. Harris. (1981) Determination of the Geographical Origin of Honeys by Multivariate Analysis of Gas Chromatographic Data on Their Free Amino Acid Content. J. Apic. Res. 20 (2): 125-135.

Gomes S., L.G. Dias, L.L. Moreira, P. Rodrigues, L. Estevinho. (2010) Physicochemical, microbiological and antimicrobial properties of commercial honeys from Portugal. Food Chem. Toxicol. 48 (2): 544-548.

Habib H.M., F.T. Al Meqbali, H. Kamal, U.D. Souka, W.H. Ibrahim. (2014) Physicochemical and biochemical properties of honeys from arid regions. Food Chem. $153: 35-43$.

Karabagias I.K., A. Badeka, S. Kontakos, S. Karabournioti, M.G. Kontominas. (2014a) Characterisation and classification of Greek pine honeys according to their geographical origin based on volatiles, physicochemical parameters and chemometrics. Food Chem. 146 : 548-557.

Karabagias I.K., A. Badeka, S. Kontakos, S. Karabournioti, M.G. Kontominas. (2014b) Characterization and classification of Thymus capitatus (L.) honey according to geographical origin based on volatile compounds, physicochemical parameters and chemometrics. Food Res. Int. 55 : 363-372.

Karabagias I.K., A.V. Badeka, S. Kontakos, S. Karabournioti, M.G. Kontominas. (2014c) Botanical discrimination of Greek unifloral honeys with physicochemical and chemometric analyses. Food Chem. 165 : 181-190.

Karabagias I.K., M.V. Vavoura, C. Nikolaou, A.V. Badeka, S. Kontakos, et al. (2014d) Floral authentication of Greek unifloral honeys based on the combination of phenolic compounds, physicochemical parameters and chemometrics. Food Res. Int. 62 : 753-760.

Krauze, A. and R. Zalewski, Classification of honeys by principal component analysis on the basis of chemical and physical parameters. Zeitschrift für LebensmittelUntersuchung und Forschung, 1991. 192(1): p. 19-23

Ojeda de Rodriguez G., B. Sulbarán de Ferrer, A. Ferrer, B. Rodriguez. (2004) Characterization of honey produced in Venezuela. Food Chem. 84 (4): 499-502.

Oliveira N.A.d., D.d.C. Santos (2011) Análise físicoquímica de méis de abelhas africanizada e nativa. Revista do Instituto Adolfo Lutz 70 (2): 132-138.

Özcan M.M., Ç. Ölmez. (2014) Some qualitative properties of different monofloral honeys. Food Chem. 163: 212218.

Pena Crecente, R. and C. Herrero Latorre, Pattern recognition analysis applied to classification of honeys from two geographic origins. Journal of Agricultural and Food Chemistry, 1993. 41(4): p. 560-564
Persano Oddo L., R. Stefanini, M.G. Piazza, M. Accorti. (1988) Diagnosis of unifloral honey. III. Application of a statistical approach to honey classification. Apicoltura 4 : 27-38.

Roubik D., P. Vit, S. R. M. Pedro. (2013) Pot-Honey: A Legacy of Stingless Bees.

Santiesteban-Hernández A., J.A. Cuadriello, G. Loper. (2003) Comparación de parámetros físico-químicos de mieles de abejas sin aguijón y Apis mellifera de la región del Sonocusco, Chiapas, Mexico, Seminario mesoamericano sobre abejas sin aguijón Tapachula, pp. 60-61.

Sanz, S., et al., Application of a statistical approach to the classification of honey by geographic origin. Journal of the Science of Food and Agriculture, 1995. 69(2): p. 135-140

Shantal Rodríguez Flores, M., O. Escuredo, and M. Carmen Seijo, Assessment of physicochemical and antioxidant characteristics of Quercus pyrenaica honeydew honeys. Food Chemistry, 2015. 166: p. 101106.

Sopade P.A., P. Halley, B. Bhandari, B. D'Arcy, C. Doebler, et al. (2003) Application of the Williams-Landel-Ferry model to the viscosity-temperature relationship of Australian honeys. J. Food Eng. 56 (1): 67-75.

Souza D.S., K. Bazlen. (1998) Análises preliminares de características físico-químicasde méis de Tiúba (Melipona compressipes), Congresso Brasileiro de Apicultura, Salvador, pp. 267-268.

Terrab A., M.J. Díez, F.J. Heredia. (2002) Characterisation of Moroccan unifloral honeys by their physicochemical characteristics. Food Chem. 79 (3): 373-379.

Terrab A., A.F. Recamales, D. Hernanz, F.J. Heredia. (2004) Characterisation of Spanish thyme honeys by their physicochemical characteristics and mineral contents. Food Chem. 88(4): 537-542.

Torres A., W. Hoffmann, I. Lamprecht. (2007) Thermal investigations of a nest of the stingless bee Tetragonisca angustula Illiger in Colombia. Thermochim. Acta 458 (1-2): 118-123.

Tuso D.J.A. (2014) Evaluación de los cambios pre y postcosecha de la miel de especies de abejas sin aguijón, Facultad de Ciencias Agrarias, Universidad Nacional de Colombia, Bogotá, pp. 208.

Vit P. (2013) Melipona favosa Pot-Honey from Venezuela, in: Vit P., Pedro S.R.M., and Roubik D. (Eds.), Pot Honey, Springer New York, pp. 363-373.

Vit P., S. Bogdanov, V. Kilchenmann. (1994) Composition of Venezuelan honeys from stingless bees (Apidae: Meliponinae) and Apis mellifera. Apidologie 25 : 278-288.

Vit P., L. Oddo, Persano, M. Marano, Luisa, E. Salas de Mejias. (1998) Venezuelan stingless bee honeys characterized by multivariate analysis of physicochemical properties. Apidologie 29(5): 377-389.

White J.W. (1975) Physical characteristics of honey. In E. Crane (Ed.), Honey, a comprehensive survey, London, UK: Hienemann. 
White J.W. (1978) Honey Adv. Food Res 24 : 287-375.

Yücel Y., P. Sultanog lu. (2013) Characterization of honeys from Hatay Region by their physicochemical properties combined with chemometrics. Food Biosci. 1 : 1625.

Zhou J., Z. Suo, P. Zhao, N. Cheng, H. Gao, et al. (2013) Jujube honey from China: physicochemical characteristics and mineral contents. J. Food Sci. 78 (3): C387-394.

Publisher's note Springer Nature remains neutral with regard to jurisdictional claims in published maps and institutional affiliations. 